\title{
The Power Of Presidential Legislation After The Amendment of UUD 1945
}

\author{
Moh. Sulfikar Suling \\ The Law Faculty of the University of Tompotika Luwuk \\ mohsulfikarsuling@gmail.com
}

\begin{abstract}
This research is to analyze and understand the accordance of the presidential legislative power after the amendment of the UUD 1945 to the presidential system principles. This legal research used statute approach, conceptual, comparative, and historical. Primary and secondary legal materials used in this study were collected through literature which investigates and inventory the legal materials with documents, literature books, law journals, and legislation related to the object of research. Legal materials that have been obtained are described and presented descriptively and analytically deduced by using the deductive method. The results showed that the presidential legislative power after the amendment of the UUD 1945 is not in accordance with the principle of the presidential system of government explicitly separating the executive and legislative branches of power in the power system as an implementation of the idea of limiting state power and the principle of popular sovereignty. The presidential legislative power after the amendment of the UUD 1945 tends to weaken the legislative function, creates an imbalance between the executive and the legislature, and inhibit the realization of the legislation in accordance with the will of the people.
\end{abstract}

Keywords: Presidential, Legislative Power, Presidential System

DOI 10.17605/OSF.IO/BX7ZA | ARK c7605/osf.io/bx7za

\section{INTRODUCTION}

The effort to change the constitution of Republic Indonesia in 1945 abbreviated by UUD 1945, is proclaimed on the principles of a modern legal state characterized by the supremacy of the law, democracy, power 
restrictions ${ }^{1}$, and the protection of human rights. The amandement to the written basic law is done in order to respond to the aspiration of the people who want a state format that is in harmony with the needs of the nation and dynamic of the times, without leaving Pancasila as a philosophy of the state or changing the national ideals that have been declared in the preamble of UUD 1945.

One of the content subject in UUD 1945 which underwent a fundamental change is the system of organizing the state power. The line of change is directed at the affirmation of the principle rule of law, the constitutional system, the rearrangement of state institutions through the redefinition of the function, the abolition of old state institutions, the establishment and the strengthening of checks and balances system among state institution.

The annual session of MPR in 1999 has formulated several points of basic arrangement in the context of amandement of UUD 1945. One of the points of the basic agreement, namely maintaining a presidential system to truly meet the general characteristics of the presidential government system (Setjen $M P R R^{2}$. The agreement aims to create a stable and democratic government in the state system of the unitary state of Republic Indonesia based on UUD 1945.

The improvement of the presidential government system can be known from the efforts of structuring the institutional system of the state including the power of the state government which is concerning to the position of the president. The position of the president as a head of the executive government and the relationship and the position of the president and the legislature (DPR) in the formation of the legislation ${ }^{3}$.

\footnotetext{
1 Jimly Asshiddiqie, Konstitusi dan Konstitusionalisme Indonesia. Second Edition, second printed. Jakarta: Sinar Grafika, 2011, p11

${ }_{2}$ Undang-Undang Dasar Sementara Republik Indonesia

${ }^{3}$ Saldi Isra, Pergeseran Fungsi Legislasi: Menguatnya Model Legislasi Parlementer dalam Sistem Presidensial Indonesia. Jakarta: Rajawali Pers. 2010., p91
}

The Power Of Presidential Legisation After The Amendment of UUD 1945

Moh. Sulfikar Suling 
The issue of legislative power has indeed become one of the crucial issues in the post-reform agenda of Indonesia's constitutional amendment. Prior to the amendment of the constitution, the regulation of the administration system in the state power has given the constitutional space for the president as the holder of the executive power as well as to exercise the legislative power. The legislative and executive powers concentrated in the hand of the president can be seen as a reflection of the strong position for the president.

The amendment of UULD 1945 has affirmed the president as the holder of the executive power (article 4 paragraph 1) and the house of representatives (DPR) as the holder of the constitution power (article 20 paragraph 1). Although the locus of the legislation formation has been transferred from the president to DPR, but the president still has a considerable power in the process of formulating the law. This can be known from the constitutional norm which gives the president the right to file a bill (article 5 paragraph 1); participates in discussing the constitution together with DPR and giving approval to the draft law (article 20 paragraph 2); rejects and approves the draft laws discussed with DPR (article 20 paragraph 3); and, ratify the draft law that has been agreed with DPR to become the law (article 20 paragraph 4). Bagir Manan ${ }^{4}$ stated that the president's power in the field of legislation is quite abroad. The president shares his power with the legislature in drafting legislation ${ }^{5}$.

Presidential government system is a model choice in establishing and managing the Indonesian state governance system since the post-reform era. From a theoretica point of view, there is a strict separation in the presidential government system between the branch functions of the executive power and the legisative power. The president as a single executive is the head of state

\footnotetext{
${ }^{4}$ Bagir Manan, Lembaga Kepresidenan. Edisi Revisi. Yogyakarta: FH UII Press. 2006, p 128

${ }^{5}$ Bagir Manan, Lembaga Kepresidenan. Edisi Revisi. Yogyakarta: FH UII Press. 2006, p 34
}

The Power Of Presidential Legisation After The Amendment of UUD 1945

Moh. Sulfikar Suling 
and the head of government whose position is separated from the parliament. In the use of the legislative function there is a separation between the legislative and the executive power. ${ }^{6}$.

Based on the above description, then the problem formulation is whether the regulation of the legislative power of the president of Republic Indonesia after the amendment of UUD 1945 has been in accordance with the principle of presidential government system. This study aims to analyze and understand the regulation of the legislative power of the president of Republic Indonesia after the amendment of UUD 1945 and its conformity with the principle of presidential government system as the choice of the Indonesian Republic government system after the amendment of UUD 1945.

\section{Research Method}

This study is categorized as legal research with the consideration that this research is based on the analysis of the constitutional norms that regulate the power of legislation of the president of Republic Indonesia after the amendment of UUD 1945 and its conformity with the principle of the presidential government system as the choice of the Indonesian Republic government system after the amendment of UUD 1945. There are four types of approaches used in this reseach, they are: Statue approach, comparative approach, conceptual approach and historical approach. ${ }^{7}$.

The technique of collecting primary and secondary legal materials used in this study are the literature or library research, it is a method of searching and inventory the primary and secondary legal materials by tracing the documents, literature books, legal journals, and the legislations related to the object of the

${ }^{6}$ Saldi Isra, Pergeseran Fungsi Legislasi: Menguatnya Model Legislasi Parlementer dalam Sistem Presidensial Indonesia. Jakarta: Rajawali Pers. 2010, p 26

7 Marzuki, Peter Mahmud. Penelitian Hukum. First Edition, Sixth Printed. Jakarta: Kencana Prenada Media. 2005, p 93-95 
research. The legal material that have been obtained will be described and presented descrptively in a more systematic writing. The methods of grammatical interpretation, systematic interpretation, historical interpretation, and telelological interpretation ${ }^{8}$, will be used as a tool in processing and analyzing the existing legal materials. Then the result of the research will be concluded by using the deductive method, that is drawing the conclusion from a thing which is general to a concrete problem which is faced in this research.

\section{DISCUSSION}

\section{The process of forming a law based on UUD 1945 after the amendment and its comparison with several constitutions.}

Based on the doctrine of Trias Politica which developed by Montesquieu, the United State governmnet system was built by strictly dividing the power of the state into three branches: the legislature, the executive and the judiciary. Strict separation between the branches of executive and legislative power is a hallmark of the US presidential government system.

This separation is regulated in the constitution of the US Article I and Article II. The US president is the holder of the highest executive power. The power of the US president is set forth in Article II Section 2 of the United State Constitution which called by "The Executive Article". In addition, the power of the US president is also listed in Article I section 7. From these various arrangements, it can be seen that the US president has not only the executive power (such as administration, foreign relation, judiciary and etc) but also has the authority that is within the scope of legislative and judicial powers. The highest legislative power is held by the US congress as it is stated clearly in Article I section 1 the United State Constitution.

8 Sudikno Mertokusumo,. Penemuan Hukum, Sebuah Pengantar. First Edition. Yogyakarta: Liberty. 1996, p 56-60

The Power Of Presidential Legisation After The Amendment of UUD 1945

Moh. Sulfikar Suling 
The United States Congress hold a major function in the formation of legisation ${ }^{9}$. According to Saldi Isra, in terms of legislation function, the United States is the first country which explicitly separate the function of legislative and executive institutions in the process of forming the laws. Alexander Hamilton in the Federalist Paper 24, 26 and 28, states that the separation of the legislative and executive powers is seen as part of the effort to prevent the formation of laws that harm the people so that the public confidence can be maintained ${ }^{10}$.

There is no article states in the Constitution of the United States determines that the president has the authority to file a draft law through a process which is known as the Executive Communication, it is by submitting a draft bill that is completed with a letter of introduction to the eadership of senate and DPR (Pataniari Siahaan, 2012: 149). According to C. F. Strong, in the practice of presidential system of the United States, the only relationship between the executive and the legislature is through a president's message and none of the presidential cabinet officer is allowed to participate in a session of one of the legislative assemblies ${ }^{11}$.

The United States Constitution also leaves no room for the government (president and ministers) to participate in the draft legislation (Isra, 2010: 88). The government's presence in this process is only at the request of a commision or sub-commission charged with the task of discussing the draft law. This mechanism is called by public hearings or a kind of hearing to ask for input or testimony from certain parties (government agencies, judiciary, experts,

\footnotetext{
9 Pataniari Siahaan, Politik Hukum Pembentukan Undang-Undang Pasca Amandemen UUD 1945. Jakarta: Konpress. 2012, p 149

${ }^{10}$ Saldi Isra, Pergeseran Fungsi Legislasi: Menguatnya Model Legislasi Parlementer dalam Sistem Presidensial Indonesia. Jakarta: Rajawali Pers. 2010, p 87

${ }_{11}$ Saldi Isra, Pergeseran Fungsi Legislasi: Menguatnya Model Legislasi Parlementer dalam Sistem Presidensial Indonesia. Jakarta: Rajawali Pers. 2010, p 88
}

The Power Of Presidential Legisation After The Amendment of UUD 1945

Moh. Sulfikar Suling 
private sector group) on the draft law which are being discussed in commission ar sub-commissions ${ }^{12}$.

The strict separation between the branches of legislative and executive powers which can be seen from the basic framework of the presidential government system is puts the legislature in full control of the legislative agenda and process. The executive has a very limited role and its involvement in the legislation process only takes place through the authority to reject od accept the draft laws which previously discussed and approved by the legislature. The executive' refusal through the veto may still be rejected by the legislature (veto override) with the support of $2 / 3$ votes from each of the existing rooms in the legislature (if the institutional structure uses a bicameral model).

The fifth French Republican Constitution is designed to limit the powers of parliament and place the executive as the central power of the state. France semi-presidenstial government system adheres to dual-executive, the president as the head of state sharing the power government with the prime minister. As described by Bagir Manan ${ }^{13}$, the president of French exercises a real power (exercises the power of government) eventhough not all of the governmental power is in his hand. The power sharing between the president and the prime minister becomes an important point for understanding the legislative function of the model of semi-presidential government system. But in the French model, the position of the president has its own uniqueness in which the president becomes a central point with great authority to control the running of the

\footnotetext{
${ }^{12}$ Pataniari Siahaan, Politik Hukum Pembentukan Undang-Undang Pasca Amandemen UUD 1945. Jakarta: Konpress. 2012, p 152-159

${ }_{13}$ Bagir Manan, Lembaga Kepresidenan. Edisi Revisi. Yogyakarta: FH UII Press. 2006, p 39
}

The Power Of Presidential Legisation After The Amendment of UUD 1945

Moh. Sulfikar Suling 
government, including the implementation of the legislative power of parliament. ${ }^{14}$.

The character of the legislative function in semi-presidential government system is that the prime minister and every parliamentarian have the right to file a draft law. But the draft law which proposed by the executive must be the main priority because it is the government that determines constitutionally the legislative agenda in the legislature ${ }^{15}$. France's fifth republican constitution is designed to strengthen the executive, so that the executive's dominance over the legislature involves in the legislation process is becoming unavoidable. The government organizes the parliamentary agenda and it is a top priority in the formation of legislation.

The French constitution affirms the executive's involvement process called "shuttle", it is a phase of discussion up to the approva of the draft law ${ }^{16}$. During the talks in the national assembly, the government may contribute to the whole or part of the draft law which is being discussed and then to be considered as input and adoption, unless the parliament rejects it. The draft laws already approved by the National Assembly are then sent by the prime minister to the president to be ratified and enacted properly within 15 days since the draft being submitted.

Prior to the amendment of UUD 1945, the establishment of the law is based on the article 5 paragraph 1 and article 20 of UUD 1945. Article 5 paragraph 1 stipulates that the legislation powers are in the hands of president with the approval of parliament (DPR). Article 5 paragraph 1 is one of the articles included in Chapter III on the power of the state government which also

\footnotetext{
${ }^{14}$ Abdul Latif. Fungsi Mahkamah Konstitusi Dalam Upaya Mewujudkan Negara Hukum Demokrasi. Yogyakarta: Kreasi Total Media. 2007, p 282

${ }^{15}$ Saldi Isra, Pergeseran Fungsi Legislasi: Menguatnya Model Legislasi Parlementer dalam Sistem Presidensial Indonesia. Jakarta: Rajawali Pers. 2010, p 85

${ }_{16}$ Pataniari Siahaan, Politik Hukum Pembentukan Undang-Undang Pasca Amandemen UUD 1945. Jakarta: Konpress. 2012, p 171-181
} 
contains in the article 4 paragraph 1 regarding the position of the president as the holder of the executive power. Therefore the power of forming the law as meant in article 5 paragraph 1 can be interpreted to be within the scope of governmental power with the president as its organ as determined in article 4 paragraph 1 of UUD 1945 before the amendment.

The matter of the law formation is also regulated in article 20 paragraph 1 of UUD 1945 before the amendment which confirms that the implementation of the power of the law formation by the president absolutely requires the approval from the parliament (DPR). In paragraph 2 stipulated if the bill does not get the approval from the House of Representatives (DPR), then the draft law should not be submitted again in the DPR session at that time. The explanation of UUD 1945 also explains that the president and DPR jointly run a "legislative power" together. However, the power to form the law remains in the hands of the president because chapter 20 and the other articles in UUD 1945 after the amendment did not mention explicitly that DPR holds the power to form the laws.

The constitution of the United States of Republic Indonesia (RIS) puts three institutions as well as the subject of the holder of the power to form the laws, they are the government, DRP and the senates. The terms of legislation are governed in articles 127-134 of the RIS constitution. The executives are actively involved in the legislative process from the stage of submission, discussion, approval, and endorsement. The degree of the executive dependence on parliamentary support and the lack of a clear separation between the executive and the legislative branches become an important part in explaining the function of the legislation in the government system ${ }^{17}$. The prevailing principles is the supremacy of parliament which places the

1717 Saldi Isra, Pergeseran Fungsi Legislasi: Menguatnya Model Legislasi Parlementer dalam Sistem Presidensial Indonesia. Jakarta: Rajawali Pers. 2010, p 79,

The Power Of Presidential Legisation After The Amendment of UUD 1945

Moh. Sulfikar Suling 
parliaments as the holder of the legislative power. However, in the absence of the strict separation and duplicate positions, the executives also participate in the legislative process of legislation.

\section{The Power of Presidential Legislation after the Amendment of UUD 1945 Within the Framework of a Presidential Government System}

In the state power system based on the presidential system, the principle of constitutional supremacy places UUD 1945 as the foundation of the people's sovereignty system and as the only basic written law and the basis of legality in exercising the people's sovereignty. This provision at the same time implies that the state of Indonesia is a democratic country which is restricted by the law made on the basis of the people will (democratische rechtstaat; constitutional democracy state). The arrangement and the distribution of the people's sovereignty implementation is executed directly by the people themselves (such as through the general election) and the state institution authorized to organize the state power by position, functions and their authorities as determined by UUD 1945. With the assertion of the sovereignty locus in the hands of the people, any state institution that carries out the functions of the state and government (beyond the judicial power) is the exercise of the people sovereignty and must submit and be accountable to the people ${ }^{18}$.

The power transfer of the law formation from the president to the house os representatives (DPR) is one part of the effort to restructure the position of the executive and legislative relations in the administration of the state government. The transfer of the legislative power to the DPR is a hallmark of the presidential system as well as the form of the implementation of people's sovereignty and the power limitation. The president's authority in the field of 2006, p 74

1818 Bagir Manan, Lembaga Kepresidenan. Edisi Revisi. Yogyakarta: FH UII Press.

The Power Of Presidential Legisation After The Amendment of UUD 1945

Moh. Sulfikar Suling 
legislation as constructed in UUD 1945 after amendment has distorted the principle of the power separation and resulted a position imbalanced between the president and DPR in the formation law. An imbalance due to the considerable authority of the presidential legislation can create the presidential dominance in the formation of laws and it potentially trigger abbuse of power by the president.

The power of the presidential legislation after the amendment of UUD 1945 is inappropiate if placed with the framework of a presidential government system. Even the power of presidential legislation after the amendment of UUD 1945 cannot be understood from the standpoint of any system government which develops in the modern democratic era which emphasizes the power of forming legislation in DPR institution. The presidential government system paces the legislature as an institution which has a wider power than the executive. The interference of the executive in the legislation process is not in line with the nature of legislation. The position of the legislature in a presidential government system embraces the explicit separation of the status and the function of the executive and legislative power branch in the administration of state power.

The right of presidential initiative as stipulated in Article 5 paragraph 1 of UUD 1945 is not unusual in the practice of legislation in the presidential government system. The drafting of the law is a routine task of members of DPR as a manifestation of the legislative function of the DPR. The drafting of laws by the executive is a hallmark of the parliamentary system because in the executive parliamentary system is part of legislature as a result of the absence of a strict separation of the executive and legislative branches.

The right of presidential initiative as regulated in Article 5 paragraph 1 of UUD 1945 obscures the position of president as the holder of the executive power and DPR as the holder of legislative power. The separation of power as 
the principle of presidential system is not completely translated. The submission of a bill by the president should be possible by members of DPR from the presidential political party.

The existence of the president's right to file a bill indirectly affects the performance of DPR and its members in the legislation process. DPR members are more passive and less creative in the legislation process. Whereas the activeness of DPR members in the legislative process is included in the drafting of the act into a measure of the realization of the responsibility of the people's legislative assembly against the mandate of the people's sovereignty mandated through the general election.

The right of presidential initiative makes it easier for the president to impose his political agenda to be embodied in legislation. The law no. 12/2011 confirms that if the president and DPR submit a draft law regulating the same material, then the draft law coming from DPR is referred to be discussed. The provision of Law no. 12/2011 becomes meaningless because in the practice, the president as the more dominant executives took the initiative to submit the bill and DPR were more passive. Especially if the majority of DPR seats are controlled by the government party or coalition of party supporters of the government, it will be easier for the president to impose his political agenda to be embodied into law.

The combination of executive dominance and the poor quality and passive attitude of DPR members assembly in the filing of laws, and the configuration of political power maps in DPR, can easily be read as a worrying dynamics if it runs out that the proposed of the draft law is not in the line with the will of the people. Under these circumstances, the strategic role of the Constitutional Court (MA) is needed to balance and control the legislative products which produce by the president and DPR to ensure that the product of the law is not contrary to the constitutional principles. 
Article 21 of UUD 1945 after the amendment gives the right to the member of DPR to propose a draft law and the right to arise from the authority of DPR as the holder of the power to form the law as stipulated in Article 20 paragraph 1 of UUD 1945 after the amendment. The position of DPR as the representative body of the people whose members are directly elected by the people through the general election reflects the existence of the people's mandate in the duties and obligations of DPR members as legislators and realize the will of the people through the act.

The right of DPR members to propose a draft law as stipulated in Article 21 of UUD 1945, has not contributed significantly in compensating the right of the presiden initiative, this is because the draft law proposed by DPR is just a proposal and not the meaning of the whole law as understood in the right of president initiative in article 5 paragraph 1 of UUD 1945. What should be proposed by the member of DPR is not just a "proposal" of the draft law, but it is a "design" intact as well as the draft law which comes from the right of presidential initiative under Article 5 paragraph 1 of UUD 1945.

After the proposed draft law from the members of DPR is discussed and approved in the plenary session of DPR, the draft is subsequently sent to the president for questioning as well as a letter requestiong that the president appoint a minister who will represent the president in discussing the draft law with DPR. This letter of DPR is often practicely interpreted as a request for the president approval of the draft law which is sent by DPR. The mechanism which is described above, indicates that the president's intervention is considerable in the formulation of legislation. The president's response letter indicates that the president's control has been started since the beginning of the legislation process.

The provision of Article 21 of UUD 1945 is also not clear when there is no strict regulation in UUD 1945 regarding the subsequent mechanism of the 
proposed draft law which is designed by the member of DPR. The advanced mechanism of the proposed draft law submitted by the members of DPR is only stipulated in Law no. 12/2011. The proposal must first be discussed in the internal of DPR and then to be approved as a draft law from the DPR itslef. Then the draft law is discussed jointly by the DPR and the president to obtain the mutual consent. Through the regulation in Law no. 12./2011, it is understandable if the proposed draft law from the members of DPR may never be a draft law if it cannot be approved in the plenary session of DPR. The follow-up mechanism in Law no. 12/2011 has reduced the meaning of the legislative power of DPR as it is defined in Article 20 paragraph 1 of UUD 1945. The provisions of the law have also narrowed the space for the members of DPR to fight for the people's aspiration in the legislation process.

The right of the members of DPR is an important part of the legislative process series in which the DPR is the holder of the power in formulating the act. The continued mechanism of the right use of the DPR members should be processed to propose the draft law regulated in UUD 1945 on the basis of understanding that the right is a unity of legislative process and the reflection of the House's affirmative as the holder of the act formulation.

The provision of the constitution and not the Law on the advanced mechanism from the right of the DPR members, reflect a guarantee of the principle realization in reaching a popular sovereignty because the members of DPR are representatives of the people that they are reprsented. The members of DPR have a professionalism, political and a moral responsibility to fight for the birth of the law in accordance with the will of the people.

The provision of Article 21 of UUD 1945 after the amendment shall be placed within the framework of the meaning of the popular sovereignty implementation. Therefore, with the power that DPR has, the members of DPR should play an active role in the legislation process through their constitutional 
rights in proposing the draft law. Everything that hiders the legislative function implementation of DPR, the right of its members to propose the draft laws and the subsequent mechanism which should be amended and be adjusted to the provision of Article 20 paragraph 1 of UUD 1945.

Furthermore, article 20 paragraph 1 of UUD 1945 after the amendment authorizes the executive to engage in the discussion and give consent to draft law into law. The involvement of the executive in the process of deliberation and the approval of the draft law is incocsistent with the principle of the presidential government system. On a non-executive system (fixed executive) or a presidential system as practiced in the United States, the president does not participate in the drafting and approval of the law that is essentially a reflection of the people's sovereignty manifestation in the legislative body as people representatives who are given the power to form a law. The exclusiveness of the legislative power held by the legislature is at the same time a consequence of the strict separation of the position and the function of the executive and legislative power branch in the administration of state power.

And so with the approval of the draft law which become an absolute law becomes the authority of the DPR, because the law is representation of the people's will in the form of a general binding law. The necessity of the president's approval in the discussion phase hapers the process of legislative aspiration by DPR. Especially if the draft law which being discussed was not in line with the president's administration policy.

The president's considerable constitutional authority in the legislation process as noted in UUD 1945 after the amendment cannot be placed in the context of the president as the head of state which is understood in the practice of parliamentary system of government. In addition for being a unifying symbol of the nation and the guardian of the state unity, the position of the state head within the framework of parliamentary system of government is intended to 
maintain a balance between government and parliament which is always tends to be unstable.

In the presidential system of government, the position of president as head of the state has merged in his position as the head of government. The amalgation was followed by a number of constitutional restrictions to prevent the concentration of the state power in the hands of the very potential president to be abused. The presidential system places the power of legislation in the hands of legislature and the power of government held by the executive (president). The strict limitation of the functions and the separation of the two branches of power were intended to create a balance between the executive and the legislatice relation in the administration of the state power system. This such restriction and segregation are also intended to avoid the emergence of state institution with the enermous powers that are difficult to control and ultimately lead to the abuse of power.

The matters concerning about the formation of a post-reform law should be built on the framework of a presidential government system that strictly separates the branches of executive and legislative power and their respective function. Jimly Asshiddiqe ${ }^{19}$ states that the separation concept of the president power which is the president as the executive (government) only acts as the implementer of the law. Even if the government is authorized to enact a legislation, then that authority should be based on the delegation of the autority which is derived from the legislator (legislative delegation of the rule-making power). Thus, based on UUD 1945 after the amendment, DPR is the only legislature and the president is the implementer of the law.

The construction of a constitutional norm which is governing the formation of the act as it is observed in UUD 1945 after the amendment, reflects

19 Jimly Asshiddiqie, Konstitusi dan Konstitusionalisme Indonesia. Second Edition, second printed. Jakarta: Sinar Grafika, 2011, p 221-224

The Power Of Presidential Legisation After The Amendment of UUD 1945

Moh. Sulfikar Suling 
the concept of functual division or the diffusion of power as the basis of the parliamentary system. The formation of legislation in the understanding of the function division and the diffusion of these powers resulted in the formation of legislation which is undertaken jointly by the executive and legislature. The executives participate in the deliberations of the bill in DPR.

The formation of the act should be interpreted as a unity of process under the line of Article 20 Paragraph 1 which affirms that the House of Representatives as the holder of power to form the law. The formation of the Act is the absolute authority of DPR within the framework of a presidential government system. Article 20 paragraph 1 of UUD 1945 after the amendment clearly states that DPR holds the power to form the laws. The phrase of "hold the power" as defined in Article 20 paragraph 1 of UUD 1945 should be interpreted as a phrase of "hold the authority". Because the power (Macht) in this case is the power to form the law (wetgevende macht), it contains the meaning of the authority in forming the Act. Because the power to form the laws is in the hand of DPR, then the submission, discussion and the approval of the draft law into law should be the authority of DPR too.

It has become a commonplace that the power to form the laws is the legislature as it is the embodiment of popular sovereignty. The legislative is one of the basic structure of democracy building. The democracy and the sovereignty of the people will lose their meaning without the existence of the legislative bodies. Therefore, the power to form a law should be the authority of DPR as a representatives institution of the people and as a manifestation of the sovereignty of the people. The legislature is tasked with channeling, translating and transforming the will of people into the normatice forms of the laws. The nature of the laws in force, forcing and suplemented with sanctions, certainly has consequences which will burden the people. The principle of democratic state reflects that the people must participate in making the rule of law which 
will burden itself and have a wide impact of everyday life. The law-making process and the resulting products must be able to provide the protection for all of the people and therefore all legal process-making and legal products must reflects the will of the people.

The creation and the application of non-linear laws with the will of the people and without the consent of the people have clearly injured the principles of democracy and the rule of the law. The legislative institution is the main buffer that strengthens the legal state's building structure. The legislature is the heart of the legal state. The state building of law will collapse and have no meaning whatsoever without the existence of the legislative institution. The legislature also elaborate the constitutional mandate in the form os law so that it becomes the basis of legality or guidance for every official and state apparatus in carrying out the government functions.

\section{SUMMARY}

The regulation of presidential legislation after the amendment of UUD 1945 has not been in accordance with the principle of a presidential government system that strictly separates the branches of legislative and executive power in the state power system as the implementation of the idea of the limiting power and the principle of popular sovereignty. The power of presidential legislation after the amendment of UUD 1945 could undermine the legislative function of DPR, creating imbalances between the executive and legislative, impeding the realization of the law in accordance with the will of the people.

\section{SUGGESTION}

Based on the conclussion that has been mentioned above, the writer proposes many suggestions, they are: 
1. For the people's consultative assembly (MPR), to make a revision of Article 5 paragraph 1 and Article 20 paragraph 2, 3, and 43 of UUD 1945. That amendment is necessary to reorganize the executive and legislative positions and relationships and also reorganize their functions in the formation of laws within the framework of the presidential government system. The position and the relation between executive and legislative in the formation of legislation must be consistent with the principles of post-reform Indonesia's State system of governance. The consistency is intended to avoid the buildup of the state power in the hands of president, created a balance between the executive and legislative positions in the administration of the state, strengthened the legislative function of DPR and ensured the establishment of a more aspirational law as a manifestation of the people's sovereignty.

2. For the legislature (DPR), to revamp the legislative performance and improve the functioning of legislative bodies and other components related to the legislation system. The members of DPR should also continue to improve the knowledge and the basic skills in terms of design of the act to maximize in guarding the voice of the people in the process of forming the act. In this case, the House of Representatives may involve the universities with greater analytical skills and knowledge resources. For the members of DPR are also expected to uphold the ethics and the law in performing their duties as legislator.

3. For the government, to further encourage the improvement of the quality of DPR in the performance of legislation. The government is also expected to increase the budget and provide other resources that support DPR in the implementation of its legislation. 
4. For the universities, to build a better coordination and good communication with DPR. In this case, the university can become a strategic partner for DPR to strengthen the philosophical, sociological and juridical content of the legislation product. The universities should also be more actively involved through the research and the development activities to strengthen and anhance the role of DPR in the formulation of state policies through the implementation of legislative function. Through the synergy of good cooperation between DPR and universities are also expected to encourage the development of science in universities, especially in the field of law science.

\section{BLIBIOGRAPHY}

\section{Books}

Asshiddiqie, Jimly. (2011) Konstitusi dan Konstitusionalisme Indonesia. Second Edition, second printed. Jakarta: Sinar Grafika.

. (2010) Perihal Undang-undang di Indonesia. Jakarta: Rajawali Pers.

Isra, Saldi. (2010) Pergeseran Fungsi Legislasi: Menguatnya Model Legislasi Parlementer dalam Sistem Presidensial Indonesia. Jakarta: Rajawali Pers.

Latif, Abdul. (2007) Fungsi Mahkamah Konstitusi Dalam Upaya Memujudkan Negara Hukum Demokrasi. Yogyakarta: Kreasi Total Media.

Majelis Permusyawaratan Rakyat Republik Indonesia. 2007. Panduan Pemasyarakatan Undang-Undang Dasar Negara Republik Indonesia Tahun 1945, Sesuai dengan Urutan Bab, Pasal, dan Ayat. Third Printed. Jakarta: Sekretariat Jenderal MPR RI. 
Manan, Bagir. (2006) Lembaga Kepresidenan. Edisi Revisi. Yogyakarta: FH UII Press.

. (2003) DPR, DPD, dan MPR dalam UUD 1945 Baru. Yogyakarta: FHUII Press.

Marzuki, Peter Mahmud. (2005) Penelitian Hukum. First Edition, Sixth Printed. Jakarta: Kencana Prenada Media.

Mertokusumo, Sudikno. (1996) Penemuan Hukum, Sebuah Pengantar. First Edition. Yogyakarta: Liberty.

Siahaan, Pataniari. (2012) Politik Hukum Pembentukan Undang-Undang Pasca Amandemen UUD 1945. Jakarta: Konpress.

Abdullah, Abdul Gani. (2004) "Pengantar Memahami Undang-Undang Tentang Pembentukan Peraturan Perundang-undangan". Jakarta: Jurnal Legislasi Indonesia Direktorat Jenderal Peraturan Perundangundangan Kementerian Hukum dan HAM RI. Volume 1, Nomor 2.

\section{Legislations}

Undang-Undang Dasar Negara Republik Indonesia Tahun 1945.

Undang-Undang Dasar Republik Indonesia 1945.

Konstitusi Republik Indonesia Serikat.

Undang-Undang Dasar Sementara Republik Indonesia.

Konstitusi Amerika Serikat (The Constitution of the United States of America).

Konstitusi Republik Kelima Perancis (Constitution of the Fifth Republic).

Undang-Undang Nomor 12 Tahun 2011 Tentang Pembentukan Peraturan Perundang-undangan.

\section{Internet}

UNDP. tanpa tahun. Governing Systems and Executive-Legislative Relations (Presidential, Parliamentary and Hybrid Systems). Melalui < http:// 
www.undp.

org/governance/docs/Parl-Pub-govern.htm>

[04/20/2014].

Jackson, Vicky. C., and Tushnet, Mark. 1999. "Comparative Constitutional Law, (New York Foundation Press), dalam Feri Amsari, Kekuasaan Parlemen dalam Sistem Pemerintahan Campuran. Melalui http: //feriamsari.wordpress. com/2010/ 04/06/ kekuasaan-parlemendalam-sistim-pemerintahan-campuran. [04/10/2014]. 